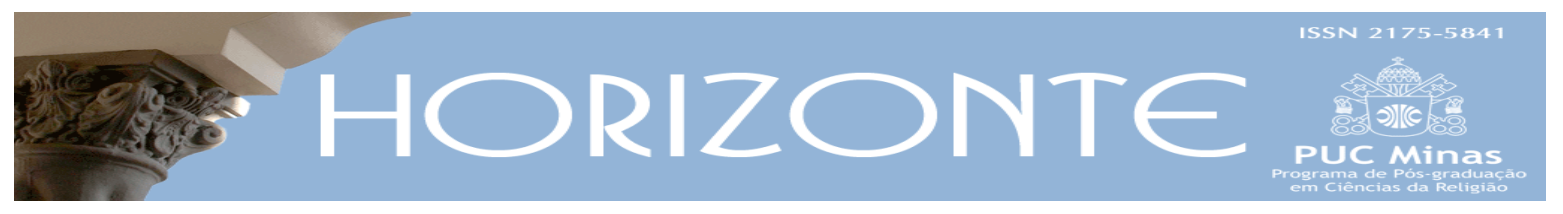

Dossiê: Política, Mídia e Religião - Artigo Original (c) (1)

\title{
Homo patiens: \\ implicações filosófico-teológicas da experiência do sofrimento
}

\author{
Homo patiens: \\ philosophical-theological implications of the experience of suffering
}

Cláudia Maria Rocha de Oliveira*

\begin{abstract}
Resumo
Este artigo tem por objetivo apresentar, a partir de uma leitura de Paul Ricoeur, a experiência do sofrimento como enigma para a razão e desafio para a fé. Os males éticos e religiosos, compreendidos como transgressão e pecado, estão relacionados a uma atitude ativa, a um fazer. O sofrimento inocente, ao contrário, deve ser pensado a partir da perspectiva da vítima. Como justificar a dor de inocentes vítimas de catástrofes, de doenças incuráveis, de violência? É possível, por exemplo, conferir sentido à experiência do sofrimento de famílias que perdem a luta contra o COVID-19? Se Deus é justo por que ele permite que os inocentes sofram? Com o objetivo de pensar a respeito destas questões dividirei este texto em duas partes. Na primeira, apresentarei como Paul Ricoeur compreende o problema do mal a partir de três dimensões: a ética da transgressão, a religiosa do pecado e a dimensão do sofrimento inocente. Na segunda, mostrarei de que modo Ricoeur pensa o sofrimento como desafio. Para Ricoeur, como veremos, a dialética tradicional não é capaz de conferir significado ao sofrimento inocente. O problema do mal exige a convergência entre pensamento e ação, e a transformação espiritual dos sentimentos. Esta transformação deve conduzir a amar a Deus de modo desinteressado. Ela pressupõe compreensão específica da relação entre amor e justiça.
\end{abstract}

Palavras-chave: Transgressão. Pecado. Sofrimento. Amor. COVID 19.

\begin{abstract}
This article intends to present the experience of suffering as an enigma to reason and a challenge to faith, following Paul Ricoeur's philosophy. Ethic and religious expressions of evil, understood as transgression and sin, are related to an active attitude, to an act of making. Innocent suffering, on the contrary, should be considered from the perspective of the victim. How to justify the pain of innocent victims of catastrophes, incurable diseases, violence? Is it possible, for example, to confer sense of the experience of the suffering of families that lose the fight against COVID-19? If God is fair, how could he allow the suffering of innocent people? The first part of the text will present how Paul Ricoeur understands the problem of evil from three main dimensions: the ethic dimension of transgression, the religious dimension of sin, and the dimension of innocent suffering. The second part will discuss the way Ricoeur regards suffering as challenge. According to Ricoeur, traditional dialectics is not able to provide meaning to innocent suffering. The problem of evil demands a convergence between thought and action, as well as the spiritual transformation of feelings. That transformation, which should lead to a disinterested love of God, assumes a specific understanding of the relation between love and justice.
\end{abstract}

Keywords: Transgression. Sin. Suffering. Love. COVID 19.

\footnotetext{
Artigo submetido em 19 de outubro de 2018 e aprovado em 10 de março de 2020.

* Doutora em Filosofia pela Pontificia Università Gregoriana. Professora da FAJE. País de origem: Brasil. E-mail: claudiamroliveira@gmail.com
} 


\section{Introdução}

A experiência do sofrimento, principalmente do sofrimento inocente, conduz a especulação a uma situação de perplexidade. É possível justificar o choro de milhares de crianças violentadas por guerras, por sistemas totalitários e por maustratos? Como consolar as vítimas de terrorismo e de perseguições religiosas? Em pleno século XXI, a humanidade foi colocada de joelhos diante de um vírus invisível. A insegurança a respeito do futuro coloca a humanidade diante de crise comparável com aquelas provocadas por guerras mundiais. A experiência do mal se reveste aqui na figura de uma pandemia. Seremos capazes de superar essa situação extrema? Se do ponto de vista da razão nos vemos confrontados com a perplexidade do real, o que podemos dizer a partir da experiência da fé? Se a razão humana é limitada e não consegue encontrar razões para a morte de milhares de inocentes, a fé seria capaz de apresentar uma saída? Onde está Deus? Por que alguns morrem e outros são assintomáticos? Quem define os critérios dessa loteria? Por que Deus não protege seus filhos diante desse mal invisível? Diante das mais trágicas situações, tais como terremotos, enchentes, incêndios, doenças incuráveis e pandemias, muitas pessoas questionam a justiça e o amor de Deus: é Ele um senhor injusto?

Ao propor uma leitura da experiência do sofrimento, a partir de Paul Ricoeur, não pretendemos fazer uma revisão bibliográfica a respeito do assunto. Nossa intenção é apenas discutir um tema que sempre se revela atual. Em todos os tempos, a humanidade sempre se confronta com o desafio de encontrar sentido para as situações. Contudo, muitas vezes, somos lançados diante de acontecimentos que deixam nossa inteligência perplexa. Mesmo a ciência mais avança é confrontada com seus limites. Como encontrar o sentido, em situações extremas? Como manter a fé, diante de situações capazes de abalar todas as certezas? 
Diante do problema do mal, a inteligência se transforma em um grande oceano de interrogações. O sofrimento dos mártires, dos judeus vítimas do holocausto, dos povos indígenas massacrados em todas as Américas, do povo palestino que habita na faixa de Gaza, dos cristãos perseguidos na Índia, dos imigrantes marginalizados e de tantas outras pessoas e povos, em todos os tempos e lugares, conduz a argumentação ao silêncio. Entretanto, o silêncio não corresponde à indiferença ou omissão, mas trata-se de um silêncio que reflete e que busca através do reconhecimento da paradoxalidade da situação uma resposta para tantas interrogações. Ora, é justamente no silêncio da não passividade e da não aceitação conformista que propomos aqui escrever algumas linhas sobre esse tema que atinge não somente a razão, mas também o coração de toda humanidade.

Todo ser humano se confronta, em algum momento, com o problema do mal que emerge com uma força tal que não o considerar é alienar-se da realidade. Ao definir este problema como "enigma para a razão” e "desafio para a fé” (RICOEUR, 1988a, p. 57), Paul Ricoeur nos ajuda a pensar. Neste artigo, ao recuperar as considerações feitas por ele, o que pretendemos é lançar luz sobre a nossa própria experiência. Ora, Ricoeur propõe pensar a experiência humana do sofrimento a partir de três dimensões fundamentais: a ética, a religiosa do pecado e a do sofrimento inocente. Ao seguir a proposta deste importante pensador francês, em primeiro lugar, apresentaremos como é possível distinguir o problema a partir de cada uma dessas dimensões fundamentais. Em seguida, refletiremos a respeito da dificuldade de encontrar sentido diante da experiência do sofrimento inocente. Veremos, finalmente, que a lógica do amor é distinta da lógica da justiça e que, portanto, será possível lançar luzes sobre a experiência do inocente apenas através de uma dialética quebrada, incapaz de conferir significado sistemático, mas habilitada a conferir amparo e consolo.

\section{0 problema do mal}

A experiência do mal coloca em evidência que nem mesmo a ciência desenvolvida nos laboratórios mais modernos do mundo é capaz de dominar a 
realidade. O real não pode ser completamente abarcado por um modelo de razão unívoco-matemático que pretenda conferir respostas claras e distintas. Neste sentido, Ricoeur defende que o problema do mal coloca em questão um modo de pensar que pretende submeter todas as experiências às regras da lógica formal e aos discursos sistemáticos totalitários (RICOEUR, 1988c, p.21). O real não é preciso nem exato. Ele é complexo e muitas vezes ambíguo. O problema do mal tem a capacidade de nos revelar os limites do nosso poder sobre o mundo. Não somos Deus. Não conhecemos completamente a realidade nem podemos dominála. Diante de um mal real, nossa inteligência é convocada à humildade. Temos que aprender. Sabemos muito pouco. A admiração e o espanto estão na base do autêntico exercício de pensamento. Quem acredita saber tudo, não é capaz de pensar.

Em consequência, um autêntico pensar a respeito do problema do mal, não pode se recusar a mergulhar no turbulento oceano de lágrimas e a reconhecer a paradoxalidade do real. Mas como pensar essa paradoxalidade? Como enfrentar o problema do mal que está na base da questão do sofrimento? Segundo Ricoeur, a primeira e fundamental atitude diante do problema do mal consiste em distinguir as suas várias dimensões: ética, religiosa e dimensão do sofrimento inocente. A princípio, é necessário, pois, estabelecer uma distinção entre mal como transgressão, mal como pecado e mal como sofrimento.

\subsection{A dimensão ética do problema do mal: liberdade e transgressão}

O mal compreendido como resultado do exercício de uma liberdade se constitui como problema ético. Neste caso, é possível identificar os culpados e impor sanções como possível reparação para o dano causado. Diante deste tipo de mal várias questões podem ser colocadas. Por exemplo: Quem é o responsável pelo mal? Por que os homens agem mal? Ao ser confrontado com esta situação, Ricoeur (1988b, p.421), propõe pensar o problema do mal a partir de um exame da constituição recíproca da liberdade e do mal. Vejamos, então, o que isso significa. 
Em primeiro lugar, se o mal está relacionado com a liberdade devemos buscar a sua origem em cada um de nós. Somos os autores do mal (RICOEUR, 1988b, pp.422). Isso significa que o mal não possui consistência ontológica própria. Ele é compreendido em oposição à boa ação. Mas, se podemos optar entre agir bem ou agir mal, a experiência do mal torna possível tomar consciência da liberdade. Esta, por sua vez, nos torna responsáveis pelas nossas próprias ações. Ora, a noção de responsabilidade nos lança em direção ao futuro. Quem age deve ser capaz de assumir as consequências do próprio ato. As consequências devem ser imputadas ao agente. Ele é o responsável pelo mal. Para Ricoeur, diante do mal ético, o sujeito deve retornar ao ato praticado e afirmá-lo não apenas como algo que fez, mas como algo que poderia ter feito diversamente. Apenas quem assume para si as consequências dos atos que realizou, mas que poderia ter realizado de outro modo, se declara livre.

A responsabilidade remete o sujeito ao futuro das consequências e ao passado do ato cometido. Este movimento é fundamental. Através dele, a identidade ética do sujeito é formada. Ela se forma, justamente, através dessa dialética entre presente, passado e futuro. Quem cometeu o erro é o mesmo que agiu e que terá que assumir as consequências pelos próprios atos. Sendo assim, “o futuro da sanção e o passado do ato cometido, ligam-se no presente da declaração” (RICOEUR, 1988b, p.422).

Contudo, a experiência nos mostra que é muito difícil ser livre. É muito difícil estarmos dispostos a assumir as consequências de nossos atos. Atualmente, temos visto, por exemplo, que diante do CODIV-19, há pessoas que preferem atribuir aos outros a culpa por suas próprias omissões. Ao transferir a culpa aos outros, no entanto, nos tornamos incapazes de nos reconhecer como livres. Deixamos, portanto, de formar a nossa identidade ética.

A consciência do erro cometido, coloca o sujeito diante de outra dimensão do problema do mal ético, a saber: a ligação entre o mal e a obrigação. A ação considerada má está intimamente ligada à consciência de que era possível agir de 
outra forma. Para Ricoeur, "a consciência de ter podido fazer de outro modo está estreitamente ligada à de ter devido fazer de outro modo”. (RICOEUR, 1988b, pp.422-423). O dever assume aqui um caráter revelador: se eu sinto, creio e sei o meu ser obrigado é porque sou um ser que não age de modo completamente determinado pelos impulsos. Também sou capaz de agir orientado pela representação da lei. Entretanto, ao mesmo tempo que descubro o meu poder de seguir uma lei, descubro também minha capacidade de agir contra a lei, mesmo que para mim ela continue sendo válida. Para Ricoeur, este agir contra uma lei que para mim não perdeu a sua validade recebe o nome de transgressão ${ }^{1}$.

Recorrendo a um exemplo recente, podemos citar a atitude do prefeito de Milão (PREFEITO, 2020). Diante do avanço do número de mortes provocadas pelo COVID-19, ele foi à mídia pedir desculpas por não ter determinado medidas de isolamento que poderiam ter impedido o colapso do sistema de saúde e, consequentemente, a morte de várias pessoas. Ele reconheceu, com o seu gesto, ser livre e, portanto, responsável por suas ações e também por suas omissões. Ao reconhecer-se como alguém que deveria ter agido de outro modo, ele assume sobre si o peso das consequências. Ele reconhece, portanto, ter transgredido uma lei, que para ele permanece sendo válida.

Não nos cabe aqui discutir as razões que o levaram a agir de determinado modo. Aristóteles, poderia nos ajudar a pensar que ele agiu de modo equivocado por desconhecer as circunstâncias particulares. Em consequência, a sua ação teria sido movida por ignorância e, portanto, deveria ser desculpada. Se ele conhecesse, efetivamente, as circunstâncias, talvez teria agido de outro modo. Não nos cabe, portanto, julgar a sua ação. Com o exemplo queremos apensar pensar se a dimensão ética do mal é suficiente para nos ajudar a compreender o sofrimento gerado por tantas catástrofes, sejam elas naturais ou não. Mesmo que o prefeito de Milão tivesse agido desde o início de outro modo, o mal poderia ter sido evitado? No caso da pandemia, sabemos que o isolamento social pode diminuir as

\footnotetext{
${ }^{1}$ Esta noção de transgressão foi defendida antes por Kant, na Fundamentação da metafísica dos costumes.
} 
consequências do mal, mas não o elimina. E, então, existe alguma outra explicação para o problema?

Outro exemplo recente poderia ser a questão da desigualdade social colocada dramaticamente em relevo pela pandemia. Milhões de pessoas sofrem no mundo por não terem acesso a hospitais e recursos capazes de garantir a sobrevivência. Neste caso, seguramente poderíamos investigar e apontar atos passados que conduziram a situação atual. Seria possível apontar culpados e exigir que seja assumida a responsabilidade pelas consequências. A desigualdade é, sem dúvida, resultado de escolhas e decisões humanas. Com certeza, uma distribuição mais igualitária dos recursos tornaria possível que milhares de vidas fossem preservadas, não apenas agora durante a pandemia, mas ao longo de toda a história da humanidade. Países europeus começaram a discutir, diante da gravidade da situação, a possibilidade de criação de uma renda básica universal, que tornaria possível proteger as pessoas da fome em tempos de crise. Isso parece uma excelente iniciativa. Contudo, também neste caso, uma menor desigualdade social, por mais que trouxesse efeitos extremamente positivos para toda humanidade, não implicaria numa superação completa do mal. Não impediria, completamente, o sofrimento inocente. Em consequência, por mais que ajude a pensar o problema do mal, a noção de transgressão não é suficiente. Ela não nos dá todas as respostas. A questão continua em aberto.

Ricoeur vai além. A própria dimensão ética do mal é marcada por um paradoxo. Como vimos, a liberdade é o meu poder de agir segundo a representação de uma lei. Mas, é justamente porque sou livre que posso agir de modo contrário à obrigação. A minha vontade possui um poder de subversão. Ao agir de modo contrário ao dever, o sujeito se descobre como dotado de arbítrio. Ricoeur define o arbítrio como sendo "o poder dos contrários, aquele que apercebemos na consciência de ter podido de outro modo, e o poder de não seguir uma obrigação que ao mesmo tempo reconheço como justa”. (RICOEUR, 1988b, p.424). Mas, como pensar esse poder da liberdade de agir contra a lei? Ricoeur pergunta pela origem comum de todas as máximas más, ou seja, pelo fundamento de todas as 
máximas que afirmam a possibilidade de transgressão da lei. Seu esforço crítico o conduz a afirmar que o fundamento das máximas más se encontra em uma condição a priori, ou seja, em uma disposição primeira da própria liberdade (RICOEUR, 1988b, pp.424-425). Portanto, está inscrita na própria liberdade uma disposição originária a agir mal. Ora, como entender esta disposição originária da liberdade? Para Ricoeur, o fundamento das máximas más aparece como um enigma. Ele se revela à reflexão como um fato: "a liberdade desde sempre escolheu mal. Este mal está já aí. É neste sentido que é radical, isto é, anterior, embora de um modo não temporal, a cada intenção má, a cada ação má”. (RICOEUR, 1988b, p.425).

O enigma deste fundamento faz emergir a consciência de um duplo limite: "limite do meu saber, limite do meu poder" (RICOEUR, 1988b, p.425). Ricoeur esclarece, então, que, de um lado, "eu não sei a origem da minha liberdade má; este não-saber da origem é essencial ao próprio ato da declaração que faço da minha liberdade radicalmente má” (RICOEUR, 1988b, p.425). O não-saber, nesse caso, torna possível o reconhecimento e a apropriação que eu faço de mim mesmo. Mas, de outro lado, "descubro o não-poder da minha liberdade. Estranho não-poder, visto que declaro ser responsável por não poder” (RICOEUR, 1988b, p. 425).

O reconhecimento do limite do meu saber e do limite do meu poder conduz, pois, à afirmação de um paradoxo. A natureza última do livre-arbítrio nos é revelada pelo mal. O livre-arbítrio possui uma marca originária que torna possível que o homem se determine de modo contrário a lei. Por um lado, portanto, o mal é o que eu poderia não ter feito. Mas, por outro lado, ao mesmo tempo, a possibilidade de fazer o mal é uma possibilidade inscrita de modo radical no meu livre-arbítrio (RICOEUR, 1993b, p. 318). A liberdade é marcada, pois, por uma contradição fundamental. Ela é caracterizada por um não-poder e, portanto, pela não-liberdade. (RICOEUR, 1988b, p.425).

Em consequência, diante do sofrimento causado por tantos males, podemos dizer que a noção de transgressão, além de não conferir resposta suficiente para o 
problema do sofrimento, nos coloca ainda diante de um paradoxo que é constitutivo da própria liberdade. Sendo assim, torna-se fundamental investigar ainda mais para tentar lançar luzes sobre esse problema que se constitui como enigma para razão e desafio para a fé.

\subsection{A dimensão religiosa do problema do mal: o pecado}

Ora, se a razão, a partir da noção de transgressão, não consegue esclarecer completamente o problema do mal, a fé teria alguma coisa a nos dizer?

Para Ricoeur, o discurso propriamente religioso sobre o mal se distingue do discurso ético porque é um discurso da esperança, que recoloca a existência numa perspectiva escatológica. A lógica da esperança não se confunde com sistematizações totalitárias, nem com o princípio de não-contradição. Ela, ao contrário, possui uma lógica própria, a saber: a lógica da superabundância, ou seja, do excesso. A lógica da superabundância permite pensar o problema do mal de modo diverso. O discurso religioso "coloca em primeiro lugar o mal perante Deus". (RICOEUR, 1988b, p. 427). O reconhecimento moral se transforma então em confissão do pecado. Invoco a Deus e confesso diante dele a minha culpa, mas, ao mesmo tempo, ao reconhecer meu pecado, reintroduzo o mal no movimento da promessa. A invocação de Deus permite a restauração de uma relação anteriormente rompida pelo pecado. $\mathrm{O}$ arrependimento possibilita $\mathrm{o}$ restabelecimento da minha ligação com Deus, de minha ligação com o outro e de minha ligação comigo mesmo.

Além disso, ao contrário do conteúdo ético do mal, que é essencialmente transgressão, ou seja, subversão de uma lei, o mal colocado diante de Deus não consiste tanto na transgressão de uma lei, mas na pretensão do homem de ser senhor da própria vida. A vontade não é constituída apenas através da relação entre arbítrio e lei, mas é constituída por um desejo de perfeição. Ora, o homem, porque possui esta vontade de realização total, se lança em busca da plenitude. Entretanto, ao querer ser patrão da própria vida, acaba se deixando conduzir por falsos 
absolutos. Nestes casos, o mal mostra o seu rosto "na mentira das sínteses prematuras, das totalizações violentas”. (RICOEUR, 1988b, p.429).

Contudo, não podemos esquecer que o homem se lança nos totalitarismos porque é intenção de totalidade, vontade de realização. O mal deve ser entendido, então, paradoxalmente como algo que faz parte do discurso da esperança, como algo que tem sua origem na lógica da superabundância. Ricoeur dirá, portanto, que "é preciso, pois, ter a coragem de incorporar o mal na epopeia da esperança; de uma maneira que nós não sabemos, o próprio mal coopera de encontro ao Reino de Deus”. (RICOEUR, 1988b, p.429). Logo, não se trata de investigar a respeito da origem do mal, mas de incorporá-lo à lógica da esperança. O discurso religioso confere, então, uma razão para a existência do mal: o mal é introduzido como elemento importante para a educação do gênero humano.

Diante dos males sofridos pela humanidade, poderíamos então interrogar se o mal nos advém para que possamos, enquanto humanidade, nos tornar melhores. Sem dúvida, diante do mal somos convocados a questionar a nossa pretensão de autossuficiência. Somos levados a reconhecer os nossos próprios limites, os limites de nossas ciências e a colocar em questão nossa pretensão de dominar a realidade. Nesse sentido, sem dúvida, o mal pode exercer a importante função de nos tornar melhores, mais humildes, mais atentos aos outros e, portanto, mais humanos.

Contudo, a experiência tem nos revelado que diante do mal as pessoas também podem se tornar ainda piores. O mal pode acentuar em nós o egoísmo e o espírito de competição. Os respiradores comprados pelo Brasil da China e barrados em aeroportos dos Estados Unidos, são um exemplo claro de que a experiência do mal não acentua apenas o que há de melhor na espécie humana. Pensar que a experiência do mal pode gerar exclusivamente uma evolução positiva da humanidade, parece pouco realista. Ao mesmo tempo que a experiência do mal pode promover uma educação do gênero humano, ela também pode acentuar o que há de pior em nós. Um excesso de otimismo com relação ao papel do mal no processo de tornar o ser humano melhor, poderia ser acusado de se pautar numa 
falsa ideia de progresso linear, pouco compatível com a complexidade característica da vida humana.

Além disso, pensar o problema do mal a partir da perspectiva da culpa supõe novamente atribuir a alguém a responsabilidade pelo mal. Será que aqueles que adquirem a forma grave do COVID-19 podem ser julgados como culpados diante de Deus? Os povos indígenas massacrados eram "impuros"? A crianças vítimas de violência já nasceram “pecadoras”? Uma possível conclusão neste sentido nos parece, no mínimo, absurda. Por mais que a lógica da esperança torne possível pensar a culpa em relação com a dimensão do perdão, ela também não parece adequada para responder, de modo completo, o problema do sofrimento inocente.

\subsection{0 escândalo do mal: a vítima}

Como vimos, o mal não se apresenta apenas como transgressão ou pecado. Além das dimensões ética e religiosa, o mal existe ainda no sofrimento inocente. Enquanto o problema do mal, tanto na sua dimensão ética quanto na sua dimensão religiosa, devem ser pensados na prospectiva do mal cometido, o sofrimento emerge como mal sofrido. Tanto o mal moral quanto o pecado designam "o que torna a ação humana objeto de imputação, de acusação e de repreensão" (RICOEUR, 1988c, p.23). Mas o sofrimento se distingue da transgressão e do pecado. Enquanto a imputação atribui a um agente responsável a culpa pela existência do mal, o sofrimento sublinha o caráter próprio de uma ação sofrida: não produzimos o mal, mas ele nos atinge. Sendo assim, o desvio ético, ou em termos religiosos o pecado, pode e deve ser denunciado. Já o sofrimento, por sua vez, “caracteriza-se como puro contrário do prazer, como não-prazer, isto é, como diminuição de nossa integridade física, psíquica e espiritual”. (RICOEUR, 1988c, p.24). Diante de um mal cometido o homem é confrontado com a repreensão. Contudo, em contraposição à censura, isto é, à repreensão "o sofrimento opõe a lamentação". Isso porque "se o erro faz do ser humano um ser culpado, o sofrimento o faz vítima”. (RICOEUR, 1988a, p.24). 
O sofrimento inocente aparece aos olhos de muitos como sem sentido ou como absurdo. Levinas (1984, p. 329) dirá que o sofrimento é um dado da consciência que se opõe a toda tentativa de articulação de sentido. Em si mesmo, ele possui uma estrutura contraditória, que não se assemelha em nada à contradição formal presente na tensão dialética entre a afirmação e a negação produzida pela inteligência, mas que se apresenta em modo de sensação. $\mathrm{O}$ sofrimento é, então, um mal que se apresenta como passividade.

Ao longo da história da humanidade não faltam relatos de vidas inocentes destruídas, de laços familiares dramaticamente desfeitos. Filhos que da noite para o dia perdem seus pais. Mães que veem seus filhos sadios partirem para sempre, sem ao menos poderem se despedir. Infelizmente, também são comuns ainda hoje os relatos de violência, de fome, de dor... O sofrimento, portanto, está ligado a uma dimensão de passividade. Como mostra Ricoeur, o sofrimento não pode ser "definido unicamente pela dor física, e nem pela dor mental, mas pela diminuição e também pela destruição da capacidade de agir, de poder fazer, que são experimentadas como um atentado à integridade do ser". (RICOEUR, 1993b, 286). O sofrimento não é produzido pelas próprias ações do sujeito atingido pelo mal. A vítima não desejou e não compreende o porquê e qual é a origem do mal que a atinge. A questão que surge é: “Por que eu?”.

Diante do sofrimento inocente, a doutrina da retribuição, que afirma uma ligação entre o sofrimento e a transgressão ou o pecado, perde a sua validade. Paradigmático aqui é o sofrimento de Jó: homem íntegro e honrado, mantém-se longe do pecado, aceita as normas éticas, pratica a justiça em sua vida social, porém, sofre. Sofre sem saber o porquê, sofre como vítima inocente. Jó, porque se reconhece inocente, rebela-se contra a doutrina da retribuição. Isto não significa que ele negue a necessidade de praticar a justiça, mas sim que ele reconhece a não possibilidade de capturar Deus em estreitas categorias humanas (GUTIERREZ, 1986, pp. 33, 166-167). 
A lamentação em Jó “corresponde a um grito dilacerante diante de uma cruel realidade”. (GUTIERREZ, 1986, p.44). O ponto de partida deste grito encontra-se numa situação dolorosa cujos motivos do sofrimento não podem ser captados pela razão. Porém, ao refletir sobre sua dor pessoal, Jó é levado a perceber que não apenas ele sofre inocentemente, mas que o sofrimento se constitui como a "situação dos pobres deste mundo que [...] morrem à margem dos caminhos". (GUTIERREZ, 1986, p.77). Gutierrez recorda, a partir da América Latina, o sofrimento dos assassinados, dos torturados, das raças humilhadas, das mulheres discriminadas, das crianças mortas ainda muito pequenas, dos desaparecidos, dos privados de liberdade, enfim, de todos "os sofridos do povo que lutam por seu direito à vida”. (GUTIERREZ, 1986, p.184). Nós poderíamos acrescentar aqui o sofrimento de todos aqueles que nos hospitais, ou fora deles, lutam pela vida sem compreender porque eles fazem parte do grupo que apresenta maiorias complicações diante do vírus que assombra a humanidade, em pleno século XXI.

A pergunta pelo problema do mal assume, assim, um tom radical: diante dos inocentes, ou seja, das vítimas, como pensar o problema do mal? Ricoeur diz que o sofrimento é "um escândalo para o pensamento e um desafio para a fé” (RICOEUR, 1988a, p.57, tradução nossa). Que devemos fazer diante desse escândalo? Devemos deixar de pensar ou aprofundar nossa pesquisa? Devemos nos entregar ao pessimismo ou nutrir a esperança de superar o mal através da via do amor, da verdade, da justiça e da graça de Deus? Diante do escândalo do mal, Ricoeur diz que não devemos nos entregar ao desespero ou ao pessimismo, que não devemos deixar de pensar. Ele nos convida a pensar ainda mais e de outro modo. Mas como podemos fazer isto?

\section{0 sofrimento como desafio}

Ao longo da história, vários foram os discursos que pretenderam dar uma resposta ao problema do mal. Os ensaios de teodiceia buscam responder ao enigma através da articulação, sem contradição, das seguintes proposições: "Deus é todo 
poderoso, Deus é absolutamente bom; contudo, o mal existe”. (RICOEUR, 1988c, p.21). Leibniz articula estas três proposições afirmando que Deus criou o melhor dos mundos possíveis. A criação aparece como resultado do êxito de uma competição entre uma multiplicidade de modelos de mundo existentes na mente divina (RICOEUR, 1988c, p.35). Deus, portanto, é um ser infinitamente bom e, graças a sua bondade, o mal existe no mundo em uma proporção mínima em relação ao bem.

Contudo, as teodiceias tiveram que reconhecer o seu fracasso. Para Ricoeur (1988c, p.36), a figura do justo sofredor instaurou uma grande desconfiança em relação à quantidade mínima do mal em relação ao bem existente no mundo: seria necessário muito otimismo para afirmar que existe no mundo um excesso de perfeição em relação às imperfeições. Fortes são, neste sentido, as palavras de Teilhard de Chardin:

É necessário ser mais realista e ter a coragem de olhar a existência de frente. Quanto mais a humanidade se torna complexa, mais as possibilidades de desordem se multiplicam e mais se acentua a sua gravidade; de fato, não se erguem as montanhas sem que se escavem os abismos, e cada energia representa uma potência tanto para o bem, quanto para o mal. Tudo o que é em transformação sofre e peca. A verdade a respeito de nossa situação neste Mundo é que nós estamos na cruz. (TEILHARD DE CHARDIN, 2001, p. 18, tradução nossa).

Além disso, toda pretensão de articulação total e harmônica de todas as dimensões da existência humana estão fadadas ao fracasso. Para Ricoeur, a dialética hegeliana, por exemplo, não deu conta de pensar adequadamente o real. Ela exclui de todo o sentido, alcançado pelo exercício de síntese, a experiência do sofrimento. Em consequência, "quanto mais o sistema prospera, mais as vítimas são marginalizadas” (RICOEUR, 1988c, p.42).

Ora, diante do fracasso das teodiceias e das dialéticas totalizantes o que devemos fazer? Renunciar a pensar? Ricoeur defende que apenas uma teologia que tenha renunciado à totalização sistemática pode empenhar-se na via de pensar o mal. Mas, existe tal teologia? Em oposição à sistematização dialética, ele irá propor, 
a partir de Karl Barth, pensar o problema do mal seguindo a lógica de uma dialética dilacerada, ou melhor, de uma dialética "quebrada".

\subsection{A dialética "quebrada"}

Karl Barth, segundo Ricoeur, no início do artigo intitulado "Deus e o nada”, afirma que "só uma teologia 'quebrada', isto é, uma teologia que teria renunciado à totalização sistemática, pode se engajar na via temível de pensar o mal”. (RICOEUR, 1988c, p.43). A dialética “quebrada” reconhece a impossibilidade de conciliar a experiência do mal com a bondade de Deus. Mas, então, como pensar a realidade do mal? Como confrontar essa realidade com o sofrimento inocente? Não há nenhum tipo de resposta ou consolo para o choro das vítimas?

Ao seguir Barth, Ricoeur defenderá a necessidade de se pensar um mal que se oponha a Deus, ou seja, um mal que se caracteriza pelo processo de corrupção e de destruição. Apenas, assim, seria possível não associar o sofrimento inocente à dinâmica da transgressão e do pecado. O sofrimento não pode ser compreendido como uma retribuição por algum mal cometido. Ele é inocente. Como, então, pensar um mal que se oponha a Deus, autor de todas as coisas? Poderíamos perguntar: se Deus criou tudo, ele também fez os terremotos, os furacões, as doenças? Mas, se ele criou tudo isso, ele é autor do mal? Se Deus é autor do mal, de que modo o mal pode ser a Ele hostil? Para Ricoeur, apenas encontraremos respostas para essas questões se formos capazes de articular, por meio da cristologia, duas afirmações fundamentais: "em Cristo, Deus venceu o mal" (RICOEUR, 1988c, p.44), mas “o nada também vem de Deus” (RICOEUR, 1988c, p.45).

Ricoeur defenderá então a tese de que Deus governa o mundo com as duas mãos: a direita e a esquerda. Estamos, pois, diante de um paradoxo: com a mão direita, Deus cria o mundo. Mas, ao criar o mundo ele faz uma eleição. Tudo o que não faz parte da eleição de Deus é alguma coisa que, enquanto rejeitada, existe como um nada. O nada é, então, criado pela mão esquerda de Deus. 
Ora, se o mal é gerado pela mão esquerda de Deus, como coordenar sem conciliar a mão direita e mão esquerda de Deus? Este é o desafio colocado pelo sofrimento inocente. Como pensar a paradoxalidade do real? Diante do escândalo do mal, como pensar, agir e sentir, em direção ao futuro e para além da teoria da retribuição?

\subsection{Pensar, agir e sentir}

Ricoeur defenderá que para enfrentarmos o problema do mal, como sofrimento inocente, é necessário mais do que o exercício de pensamento. Torna-se fundamental uma tomada de atitude, tanto no sentido ético quanto no sentido político, e também uma transformação profunda dos sentimentos (RICOEUR, 1988c, p.47).

No plano do pensamento, o mal se apresenta como desafio. O mal deve ser compreendido como uma categoria da ação e não da teoria. Ele precisa ser reconhecido como um dado teoricamente inexplicável. Contudo, o reconhecimento da incapacidade de todas as teorias filosóficas de encontrar uma resposta definitiva para o escândalo do mal não implica deixar de pensar, mas revela um enriquecimento que deve reforçar a lógica especulativa. A ignorância, neste caso, possui um valor libertador.

A ação e a espiritualidade, por sua vez, devem assumir a tarefa de "continuar o trabalho de pensamento no registro do agir e do sentir”. (RICOEUR, 1988c, p.48). O mal se revela do ponto de vista da ação como sendo aquilo que não deveria ter lugar e que, portanto, precisa ser evitado e combatido. Diante do mal na sua dimensão prática, o sujeito deve se colocar a pergunta a respeito do que pode ser feito como resistência ou luta contra o mal. O pensamento se dirige então à ideia de uma tarefa a perseguir.

Isso significa que diante do mal não podemos deixar de buscar uma saída. Diante da pandemia, por exemplo, mesmo reconhecendo os limites do nosso conhecimento, é necessário usar todas as forças e todos os meios disponíveis para 
encontrar remédio e vacina capazes de conter o mal. Também é necessário um empenho de todos para que a fome e o desemprego não tornem ainda mais grave o sofrimento já causado pela questão sanitária. Garantir assistência hospitalar a todos, também deveria ser uma bandeira defendida. A resistência contra o mal precisa acontecer, portanto, de maneira ativa. Independente de qual for o mal, as perguntas fundamentais poderiam ser, então, as seguintes: como nos mobilizar para enfrentar a situação? Como agir contra o mal?

De modo semelhante a Ricoeur, Teilhard de Chardin também defende a necessidade de assumir postura ativa diante do mal. Segundo ele,

é de suma importância para o cristão entender e viver a vontade de Deus em sentido ativo [...]. Para praticar integralmente a perfeição de seu cristianismo, o cristão não deve desertar diante do dever de resistir ao mal. Ao contrário, num primeiro momento, ele deve lutar sinceramente e com todas as forças, em união com a potência criadora do Mundo, a fim de fazer recuar todo o mal (TEILHARD DE CHARDIN, 2001, p.18, tradução nossa).

Paul Ricoeur esclarece que, como cada mal cometido por alguém é sempre um mal sofrido por outra pessoa, fazer o mal é fazer alguém sofrer. Logo, se a violência diminui, consequentemente, diminui também o sofrimento no mundo. No nível do agir se trata, pois, de procurar amenizar o sofrimento no mundo, isto significa que, “antes de acusar Deus ou de especular sobre a origem demoníaca do mal no próprio Deus, atuemos ética e politicamente contra o mal”. (RICOEUR, 1988c, pp.48-49).

Entretanto, não basta agir contra o mal. Existe uma causa de sofrimento que transcende a ação injusta dos homens: catástrofes naturais, doenças e epidemias, envelhecimento e morte. Diante do sofrimento sem explicação o ser humano se questiona “por que eu?”. Ricoeur acrescenta, então, à resposta prática uma resposta emocional. Trata-se de acordo com ele, de um processo de espiritualização do sofrimento. Este processo se dá a partir de três etapas. 
Na primeira, somos constringidos a renunciar à pretensão de elaborar uma síntese total e harmônica capaz de englobar o mal, e somos conduzidos a reconhecer a nossa ignorância diante do mal inexplicável. É indispensável, aqui, reconhecer que eu não sei por que as coisas acontecem assim. Também é necessário reconhecer que não foi Deus que quis que as coisas fossem assim. O sofrimento não é uma punição por nenhum tipo de pecado cometido. A doutrina da retribuição precisa ser, portanto, completamente deixada de lado. Neste primeiro nível, é necessário que o mal apareça de fato como um escândalo, como algo não merecido (RICOEUR, 1988c, p.50).

A segunda etapa da espiritualização da lamentação é o estágio da revolta. Consiste em “deixar-se expandir numa queixa contra Deus” (RICOEUR, 1988c, p.51). Para Gutierrez, por exemplo, a revolta de Jó se dirige contra "a interpretação da relação do ser humano com Deus baseada na retribuição”. (GUTIERREZ, 1986, p.70). As palavras de Jó, portanto, são uma crítica a toda teologia desligada do contato com a realidade e da compaixão humana: Jó entra num verdadeiro combate espiritual com Deus, mas esse combate é animado por uma sólida experiência de Deus. Nesta segunda etapa, o protesto se dirige contra a ideia de permissão divina. O mal é, então, mantido na dimensão prática. Ele é, ainda uma vez, aquilo contra o qual nós lutamos.

Finalmente, na última etapa da espiritualização da lamentação, eu descubro que "as razões de acreditar em Deus não têm nada em comum com a necessidade de explicar a origem do sofrimento". (RICOEUR, 1988c, p.51). Uma espiritualização da lamentação conduz a reconhecer que creio em Deus apesar do mal, creio em Deus, não obstante o mal. Belas, neste sentido, são as palavras de Teilhard de Chardin:

Nas horas em que a estrada diante de nossos passos se faz obscura, a única e grande oração que se pode fazer é aquela do Mestre da Cruz 'In manus tuas commendo spiritum meum'. Nas mãos que partiram e distribuíram o pão, que concederam a benção e acariciaram, que foram traspassadas, [...] nas mãos doces e poderosas que penetram até o centro da alma, - que plasmam e que criam -, naquelas mãos nas quais passa um grande amor, é doce abandonar a própria alma, especialmente quando há sofrimento e medo. E ao fazer isso, é possível experimentar uma grande felicidade. (TEILHARD DE CHARDIN, 2001, p.24, tradução nossa). 
A lamentação permanece sempre prisioneira da retribuição. Uma espiritualização da lamentação conduz a amar a Deus por nada, ou seja, conduz a renunciar ao desejo de ser recompensado pelas próprias virtudes, ao desejo de ser poupado do sofrimento. Conduz, pois, a sair completamente do círculo da retribuição. Ricoeur (1988a, p. 63) afirma que no fim do livro de Jó, a única coisa da qual Jó se arrepende é do seu lamento. E é justamente quando se arrepende de ter lamentado que Jó se torna capaz de amar a Deus por nada.

Contudo, esta descoberta da possibilidade de amar a Deus apesar do mal só é possível graças a uma "sabedoria pessoal que não pode ser ensinada aos outros sem a pena de tornar-se imediatamente uma falsificação e uma mistificação”. (RICOEUR, 1988, p. 63, tradução nossa). Neste sentido, Ricoeur defende que "nós nada podemos dizer aos outros sobre o sofrimento deles”. A sabedoria pessoal que permite romper o círculo da lamentação "não pode ser ensinada, sob pena de reconduzir o outro à autoacusação e à autodestruição”. (RICOEUR, 1988, p.63, tradução nossa).

O sofrimento, portanto, continua sem ter um sentido que possa ser apreendido pela razão e traduzido num discurso capaz de confortar aqueles que sofrem. Mas é a partir da própria vivencia da experiência do sofrimento, que quem sofre pode ser capaz de descobrir um sentido não para a própria dor, mas um sentido para além da dor. Um sentido que se revela, exclusivamente, na experiência do amor desinteressado.

Mas o que significa amar a Deus por nada? Não se pode esperar de Deus um consolo para o sofrimento? Afirmar a inocência da vítima, a partir da doutrina da retribuição, seria, ao mesmo tempo, afirmar a injustiça cometida por Deus. Mas, como afirmar, a partir de uma religião desinteressada, a inocência da vítima e a justiça de Deus? O amor e a gratuidade de Deus são incompatíveis com a justiça? Como crer em Deus não obstante o mal? É possível encontrar através de uma articulação dialética entre o amor e a justiça um sentido para o sofrimento? 


\subsection{0 amor e a justiça}

No texto Amor e Justiça, Paul Ricoeur propõe uma dialética entre os termos amor e justiça, reconhecendo a "desproporção" entre eles e, ao mesmo tempo, buscando uma mediação prática "entre os dois extremos" (RICOEUR, 2012, p. 3).

Para Ricoeur (2012, pp.5-15), o discurso do amor possui uma estranheza caracterizada por três aspectos: pela ligação do amor com o louvor; pelo emprego da forma imperativa em expressões como, por exemplo, "amarás o Senhor teu Deus"; e, por fim, pelo uso de expressões que se dirigem ao amor enquanto sentimento, através de uma linguagem metafórica.

No louvor, o ser humano se satisfaz diante de um objeto que emerge acima de todos os outros e que, por isso, atrai a sua atenção. À luz dessa definição emergem os traços da nova religião do amor defendida por Jó: apesar de todo o sofrimento, Jó elevou sua atenção a Deus, não para negá-lo, mas para reconhecer que Ele está acima de toda a dor e de todo o mal.

A segunda estranheza característica do discurso do amor diz respeito ao emprego da forma imperativa em expressões que "ordenam" o amor. Se o amor assumisse a forma de um dever, como, por exemplo, no caso da obrigação que o imperativo categórico kantiano exprime, a religião do amor não seria uma religião gratuita, mas sim da obrigação. Entretanto, Ricoeur ressalta que o mandamento do amor apenas tem sentido se admitirmos que ele contém em si mesmo as condições da sua própria obediência.

A terceira estranheza é a capacidade das metáforas de revelar um dinamismo do amor. Elas mobilizam em nós uma pluralidade de sentimentos, às vezes até mesmo antagônicos, através dos quais se torna possível exprimir e significar o amor. (RICOEUR, 2012, p.15). 
A justiça, por sua vez, é considerada, por Ricoeur, em dois níveis distintos: no nível da prática social e no nível dos princípios de justiça. A justiça entendida no nível reflexivo da prática social se opõe ao amor (RICOEUR, 2012, p.18). Essa oposição se deve à identificação da justiça com a justiça distributiva. Já a justiça entendida a partir do nível dos princípios de justiça está diretamente ligada, para os moralistas, com a noção de igualdade.

Como meio-termo dialético entre amor e justiça, Ricoeur (2012, pp.23-36) apresenta, então, o que ele denomina como a economia da doação. Ela é, segundo ele, a única capaz de fundamentar o mandamento de amar os próprios inimigos. E seria, portanto, em nossa reflexão sobre sofrimento, a única capaz de garantir a existência de uma religião desinteressada, ou seja, de garantir a possibilidade de amar Deus por nada.

A economia da doação está acima da ética porque nela o homem é interpelado enquanto criatura. Como criatura o homem se percebe numa dependência radical de seu criador que o situa no meio de uma natureza entendida como objeto de solicitudes, respeito e admirações. Mas, é da economia da doação que também depende a relação do homem com a lei e com a justificação. Por um lado, “a lei é doação, na medida em que está ligada à história de uma libertação”. (RICOEUR, 2012, p.24-25). Por outro lado, a justificação "também é doação, na medida em que é perdão gratuito”. (RICOEUR, 2012, p.25). Através da economia da doação, que se situa então “entre’ criação e escatologia” (RICOEUR, 2012, p.25), Ricoeur diz estabelecer uma mediação dialética entre amor e justiça.

Esta mediação dialética é caracterizada pelo paradoxo: a economia da doação se localiza entre uma lógica da superabundância e uma lógica da equivalência, ou seja, entre o mandamento novo instituído por Jesus, isto é, o mandamento do amor, e a regra de ouro, que em certos casos assume a forma de regra de justiça. Estas duas lógicas, a princípio, são opostas entre si. 
A regra de ouro depende inevitavelmente de uma lógica da equivalência à medida que exige a instauração de uma relação de reciprocidade ou de reversibilidade. Já o mandamento novo, ao afirmar que devemos amar aos nossos inimigos, isto é, ao exigir um amor gratuito e desinteressado, parece negar a reciprocidade e reversibilidade. Como essas duas realidades se conciliam através da mediação da economia do dom?

Segundo Ricoeur, "o mandamento do amor não abole a Regra de Ouro, mas a reinterpreta no sentido da generosidade". (RICOEUR, 2012, p. 29). Essa reinterpretação, contudo, não se dá harmonicamente, mas sempre numa relação de tensão entre a lógica da superabundância e a lógica da equivalência. Uma dialética entre amor e justiça deve permitir, portanto, que a lógica da equivalência no confronto com a lógica da superabundância, se eleve "acima das suas perversas interpretações". Isto porque "sem o corretivo do mandamento do amor, a Regra de Ouro seria incessantemente puxada no sentido de uma máxima utilitária". (RICOEUR, 2012, p.30).

A lógica da superabundância não é uma lógica imoral, mas está num nível acima da ética, e, por causa dessa sua posição, a sua função consiste em reorientar e corrigir a regra da justiça. Por outro lado, entretanto, Ricoeur afirma que a tarefa da filosofia consiste em mostrar "que é somente no juízo moral em situação que esse equilíbrio instável pode ser instaurado e protegido”. (RICOEUR, 2012, p.33).

\section{Enfim, há sentido para o sofrimento?}

Mas, como pensar, a partir da economia da doação, o problema do sofrimento? Para Gustavo Gutierrez "não há circunstância humana que nos coloque mais distante da aceitação do amor gratuito de Deus que nossa própria experiência do sofrimento". Porém, se a partir do sofrimento somos capazes de viver a fé "com desinteresse e encontrar a linguagem adequada para falar de Deus, então o Deus da bíblia pode ser reconhecido autenticamente pelo ser humano”. (GUTIERREZ, 1986, p.52, tradução nossa). 
A pergunta que se apresenta, portanto, é a seguinte: a economia da doação, meio-termo da relação dialética entre o amor e a justiça, pode nos ajudar a sair do impasse diante da aparente absurdidade do sofrimento? Ricoeur, como já disse, situa a economia da doação entre a criação e a escatologia. Ao partir desta perspectiva, ele parece indicar que apenas nesse terreno é possível superar o aparente não-sentido do mal como sofrimento, conferindo a ele uma ordem e um significado. O outro caminho, como vimos, seria através da espiritualização da lamentação.

Contudo, por um lado, uma economia da doação, que se situa entre a criação e a escatologia, nos faz suspeitar de um interesse último do homem-criatura pela sua salvação. E nos faz suspeitar, ao mesmo tempo, de um não-abandono completo da noção da doutrina da retribuição. Parece, portanto, muito mais fácil pensar a radicalidade do amor gratuito e desinteressado de Deus pela humanidade do que pensar uma iniciativa desinteressada da parte do homem em sua relação com Deus. De todo modo, amar a Deus por nada se apresenta como o grande desafio para toda a criatura.

Por outro lado, é preciso sublinhar que para Ricoeur, afirmar uma perspectiva suprassensível, que se estende da criação à escatologia não significa compactuar ou justificar as injustiças terrenas disfarçadas de justiça. Não supõe legitimar e se calar diante de um poder político que explora. Não implica conformar-se dizendo que foi "Deus quem quis assim". Temos que reunir todas as nossas forças para combater o mal. Neste sentido, Teilhard de Chardin esclarece que

encontrar e cumprir a vontade de Deus [...] não é encontro imediato nem posicionamento passivo. Se sou atingido por um mal graças a minha negligência não terei o direito de pensar que se trate da Mão de Deus. A Vontade de Deus [...], eu não encontrarei senão no extremo limite das minhas forças. (TEILHARD DE CHARDIN, 2001, p. 79, tradução nossa, itálico do autor). 
Para Ricoeur, afirmar uma perspectiva suprassensível, que se estende da criação à escatologia significa seguir o exemplo de Jó que se rebelou contra o sofrimento inocente, contra a teologia que justificava esse sofrimento e inclusive contra a imagem de Deus que essa teologia apresentava. Como esclarece Gutierrez, "em Jó, ter fé supõe comungar com os sofrimentos humanos, em especial dos mais desvalidos, passar por um combate espiritual e aceitar finalmente que não se pode aprisionar Deus em categorias humanas". (GUTIERREZ, 1986, p.55, tradução nossa). Neste sentido, "apenas tomando em sério a dor da humanidade, o sofrimento do inocente, e vivendo sobre a luz pascal o mistério da cruz em meio dessa realidade, será possível evitar que nosso discurso seja um discurso vazio". (GUTIERREZ, 1986, p.186, tradução nossa).

Diante do sofrimento inocente, a confiança na justiça de Deus implica, portanto, romper com as imagens de Deus aprisionadas em categorias humanas e se abrir à gratuidade de um Deus que confere sentido ao sofrimento do inocente através do seu próprio sofrimento na cruz. Teilhard de Chardin defende que, "ao longo de sua paixão, Jesus sentiu gravar em sua alma, abandonada e enfraquecida, o peso de todas as dores humanas em uma prodigiosa síntese. Ele as assumiu e experimentou". Além disso, ao introduzir "todas as dores da humanidade em sua consciência, Cristo as transfigurou". Pecado e sofrimento, que antes "eram como as 'escórias' da Terra", agora, "pela virtude da Cruz", tornaram-se preciosos. (TEILHARD DE CHARDIN, 2001, 19, tradução nossa).

A justiça de Deus não é uma justiça que se enquadra nos moldes da justiça dos tribunais, e o amor de Deus, embora não seja imoral ou injusto, transcende o campo da moral e confere um sentido escatológico ao sofrimento do homemcriatura. De acordo com Gutierrez "a justiça de Deus só pode ser entendida no interior de seu amor primeiro e gratuito". (GUTIERREZ, 1986, p. 125, tradução nossa). Logo, "a gratuidade do amor de Deus é o marco em que se inscreve a exigência de praticar a justiça". (GUTIERREZ, 1986, p. 163, tradução nossa). Contudo, "não se trata de enfatizar o lúdico e o gratuito contra o justo, mas de fazer 
que o mundo da justiça encontre seu pleno sentido no amor livre e fontal de Deus”. (GUTIERREZ, 1986, p. 174, tradução nossa).

\section{Conclusão}

Diante do problema do mal e do sofrimento inocente podemos então recolocar as questões que deram origem a essa investigação. Por que passamos por essas situações? Por que existe o mal? É possível encontrar sentido para o sofrimento inocente? O sofrimento é um castigo? Mas, se sou bom, se pratico a justiça, porque sofro? Deus é mesmo um ser justo? O amor de Deus é compatível com a justiça?

Vimos que, diante do problema do sofrimento inocente, a razão não dá conta de propor uma resposta sistemática e total. Mesmo a transgressão e o pecado parecem possuir na sua própria estrutura constitutiva uma dimensão paradoxal. Como, então, nos posicionar diante da dor e do sofrimento sem explicação?

Em primeiro lugar, é necessário um empenho coletivo contra o mal. Temos que ser capazes de utilizar todos meios necessários para vencer o inimigo, seja ele o vírus invisível, a desigualdade social bem mais visível, que produz falta de assistência, desemprego e fome, sejam as consequências de furacões, terremotos, acidentes ou catástrofes. Em seguida, não podemos nos considerar como merecedores do mal sofrido. Temos que reconhecer a injustiça do sofrimento e nos rebelar contra toda a imagem de Deus que a possa justificar. Não foi Deus quem quis assim. O mal não é obra do querer de Deus. Finalmente, precisamos reconhecer que o amor de Deus não corresponde aos critérios da justiça em termos humanos. O amor de Deus é infinito e gratuito. Logo, se queremos amar a Deus precisamos aprender a amá-Lo também de modo desinteressando.

Isso não torna possível alcançar uma formulação teórica que dê conta de responder à questão a respeito do sentido do sofrimento. Mas, a espiritualização da lamentação promove uma conversão profunda que faz com que diante do 
sofrimento sejamos capazes de agir de outro modo. Somos conduzimos a reconhecer que, se Deus é amor infinito, não estamos nunca sozinhos. Ao contrário, é Ele quem nos anima na luta contra o mal. Portanto, Deus está e estará sempre ao nosso lado, nos ajudando a superar os momentos mais duros da história.

Quem sofre, portanto, não está só. Deus está do lado de todo aquele que chora e sofre, e também do lado de todo aquele que sorri e se alegra. Deus é um pai presente ainda que nós, seus filhos, nos momentos escuros de nossas vidas, não sejamos capazes de reconhecer a sua presença. Deus, portanto, estava ao lado de todos os judeus vítimas do holocausto, dos povos indígenas massacrados em todas as Américas. Ele está ao lado do povo palestino que habita na faixa de Gaza, dos cristãos perseguidos na Índia, dos imigrantes marginalizados, dos desempregados, das famílias que perderam a luta contra o COVID-19. E ele sempre estará ao lado de todas as pessoas que sofrem. Como Pai amoroso e justo, Deus não abandona os seus filhos, mas os consola e ajuda a superar todo sofrimento. E é justamente porque Ele sempre nos acolhe em seus braços, que nós devemos aprender a amáLo não obstante o mal. Devemos aprender a amá-Lo como Ele nos ama, isto é, devemos amá-lo de modo gratuito e desinteressado.

Portanto, se, por um lado, não é possível encontrar através da razão, uma resposta capaz de satisfazer todas as nossas questões diante do sofrimento inocente, por outro lado, através da nossa ação e do nosso afeto podemos encontrar consolo e força no amor misericordioso de Deus. Assim, também nós, por mais que não possamos explicar a nenhuma pessoa as razões de seu sofrimento inocente, podemos ser para elas, através da ação e dos afetos, sinal de esperança e amor. Este é o grande desafio! 


\section{REFERÊNCIAS}

ARISTÓTELES. Ética a Nicomaco. São Paulo: Abril Cultural, 1973. p. 245-436. (Coleção os Pensadores, IV).

CINQUETTI, Mauro. Pensare di più, pensare altrimenti: Paul Ricoeur e la sfida del male. PARMA, 2003. Tese (Doutorado em Filosofia), Faculta di Lettere e Filosofia: Universita degli studi di Parma.

GUSTAVO, Gutierrez. Hablar de Dios desde el sufrimento del inocente: Una reflexion sobre el libro de Job. Lima: Instituto Bartolomé de las Casas; Centro de Estudios y publicaciones, 1986.

JERVOLINO, Domenico. Introduzione a Ricoeur. Brescia: Morcelliana, 2003.

KANT, Immanuel. Fundamentação da Metafísica dos Costumes. In: KANT, Immanuel. Critica da razão pura e outros textos filosoficos. São Paulo: Abril Cultural, 1974.

LEVINAS, Emmanuel. La souffrance inutile. Les cahiers de la nuit surveilée, Paris: Verdier, p. 329-338, 1984.

LÉVINAS, Emmanuel; MARCEL, Gabriel; RICOEUR, Paul. Il pensiero dell'altro. Roma: Edizioni Lavoro, 1999.

PREFEITO de Milão admite erro por ter apoiado campanha para cidade não parar no início da pandemia de coronavírus. Bem Estar. G1. 07 de março de 2020. Disponível em https://g1.globo.com/bemestar/coronavirus/noticia/2020/o3/27/prefeito-de-milaoadmite-erro-por-ter-apoiado-campanha-para-cidade-nao-parar-no-inicio-da-pandemiade-coronavirus-na-italia.ghtml Acesso em o9 de março de 2020.

RICOEUR, Paul, Le scandale du mal. Esprit, Paris, v. 140/141, n. 7/8, p. 57-63, juil.-août 1988a.

RICOEUR, Paul. Amor e justiça. São Paulo: Martins Fontes, 2012.

RICOEUR, Paul. O conflito das interpretações: ensaios de hermenêutica. Porto: Rés Editora, 1988b.

RICOEUR, Paul. O mal: um desafio à filosofia e à teologia. Campinas: Papirus, 1988c.

RICOEUR, Paul. Sè come un altro. Milano, Jaca Book, 1993b.

SILVA, Eduardo, S.J., El mal en la reflexion de Paul Ricoeur, In. CASAS, Vicente Durán; SCANNONE, Juan Carlos; SILVA, Eduardo. Problemas de filosofia de la religión desde América Latina: la religión y sus limites. Bogotá: Siglo del Hombre Editores, 2004, p. 119-152.

TEILHARD DE CHARDIN, Pierre. Sulla Sofferenza. Brescia: Queriniana, 2001. 